\title{
Comparing the Change of Teaching Motivations among Preservice Teachers in Austria, Germany, and Switzerland: Do In-school Learning Opportunities Matter?
}

\author{
Johannes König $^{1}$, Martin Rothland ${ }^{2}$, Sarantis Tachtsoglou ${ }^{1}$ \& Stefan Klemenz ${ }^{1}$ \\ ${ }^{1}$ Empirical School Research, University of Cologne, Germany \\ ${ }^{2}$ University of Siegen, Germany \\ Correspondence: Johannes König, Empirical School Research, University of Cologne, Gronewaldstr. 2, 50931 \\ Cologne, Germany, Tel. 49-(0)-221-470-6145, Fax: 49-(0)-221-470-49-51, E-mail: johannes.koenig@ uni-koeln.de
}

Received: June 22, 2016

Accepted: July 14, 2016

Online Published: July 18, 2016

doi:10.5430/ijhe.v5n3p91

URL: http://dx.doi.org/10.5430/ijhe.v5n3p91

\begin{abstract}
In this study, we examine the hypothesis that preservice teachers' teaching motivations change during the first two years of their teacher preparation. A sample of 1,779 student teachers with two time points from Austria, Germany, and Switzerland is used. Findings show that student teachers' intrinsic motivation increases, whereas their extrinsic motivation being more distal to initial teacher education does not change. Against our expectations, their altruistic-type motivation (e.g., the motivation to work with children/adolescents) tends to deteriorate. The change of teaching motivations is influenced by in-school opportunities to learn (teaching practice activities, support by school mentors) and it is more practically relevant in a teacher education context where practical training is given high priority (Austria, Switzerland) compared with a context that heavily focuses on theoretical study (Germany). We discuss implications for teacher education from a comparative perspective and give an outlook for possible future research.
\end{abstract}

Keywords: Motivation, Preservice Teacher Education, Field Experience, Opportunities to Learn

\section{Introduction}

International research has identified the career choice motivation of future teachers as a relevant factor in the admission to, the progression and graduation of a teacher education program (cf. Darling-Hammond \& Sykes, 2003; Rots, Aelterman, Devos, \& Vlerik, 2010; Thomson, Turner, \& Nietfeld, 2012; Watt \& Richardson, 2008; 2012). Although investigations in the field usually provide descriptions of the quality and frequency of preservice teachers' motivation (cf. Brookhart \& Freeman, 1992; Kyriacou, Hultgren, \& Stephens, 1999; Moran, Kilpatrick, Abbott, Dallatt, \& McClune, 2001; Richardson \& Watt, 2010; Sinclair, 2008), hardly any study has used a design with two or more time points to examine whether teaching motivations change during initial teacher education and how they are shaped by specific learning opportunities provided by teacher education programs. As a consequence "we yet lack evidence for whether teacher motivation can be changed" during teacher education (Opfer, 2014, p. 220).

Against this background, in this article we examine how student teachers' motivations for teaching as a career change during initial teacher education and how they are shaped by practical learning opportunities. Our conceptual framework generally follows the design that was created in the Teacher Education and Development Study in Mathematics (TEDS-M; Tatto et al., 2012), a comparative study conducted in 17 countries. According to proposed interrelationships of the TEDS-M conceptual framework (Tatto et al., 2008, p. 14), we analyze teaching motivations of preservice teachers in their third year of training as learning outcome, whereas teaching motivations the preservice teachers had when entering are considered to be entrance characteristics. The concept of opportunities to learn (OTL) is applied to describe specific characteristics of teacher education programs, which are in turn determined by contextual factors on the national level of a country (i.e., its teacher education system). So we investigate our research question from a comparative perspective, including future teachers from a selection of three countries: Germany, Austria, and Switzerland. Taking these countries as a source of natural variation, our comparative investigation contributes to the global discourse of teaching and teacher education (Townsend \& Bates, 2007; Wang et al., 2011) and provides important insights into strengths and weaknesses of the teacher education programs and systems involved, thus enriching current reform debates in the German-speaking countries (Hascher, 2014; Rothland 
\& Boecker, 2014).

\subsection{Change of Teaching Motivations during Teacher Education}

Reviews of teaching motivation research (Rothland, 2014; Richardson, Karabenick, \& Watt, 2014) show that issues of change over time have not been accounted for by empirical studies. Instead, high stability is assumed, since preservice teachers would generally hold their decision to become a teacher once they have entered initial teacher education (Rothland, 2014). As a consequence, there is a research deficit regarding the examination of how motivational characteristics of preservice teachers change (Opfer, 2014).

According to the well-known theory of vocational choice by Holland (1997; cf. Nauta, 2010), a person develops his or her vocational decisions on the basis of her personal experience gained in contexts relevant for that vocation. Following his theory, the question arises which elements of initial teacher education are relevant for providing such contexts. We assume that in-school opportunities to learn related to teaching practice (sometimes denoted as 'field experience', Tatto et al., 2012, p. 34, 'practice', Ball \& Forzani, 2009 or termed as 'learning about practice in practice', Darling-Hammond et al., 2005) would be particularly important, being closer to teaching as a vocation when compared with usual coursework at university.

How future teachers' school experience may influence their teaching motivations remains an open question, though (Clift \& Brady, 2005; Rothland, 2014; Richardson, Karabenick, \& Watt, 2014). Motivations for teaching can result in participation in a teacher education program, and thus may be regarded as the "first step in becoming a teacher" (Sinclair, 2008, p. 81). But reflecting about one's vocational choice seems to be highly relevant even after having entered initial teacher education, since experiences the students teachers have gained previous to initial teacher education may be of limited scope. Among the various forms of experience a person gains and that contributes to his or her decision to become a teacher, the experience gained in the role of a student at school is paramount (Lortie, 1975). If initial teacher education is understood as an enterprise in which a student teacher's professional development is to be fostered, then role-taking is essential, comprising the change of a student's view on teaching and school into a more professional teacher's view. Therefore, that preservice teachers are required to self-critically re-examine their teaching career decision during school practice is an important curricular objective outlined in many teacher education programs (Arnold et al., 2011; König et al., 2014; Mayr \& Rothland, 2013; Wilson, Floden, \& Ferrini-Mundy, 2001).

\subsection{Opportunities to Learn}

Opportunities to learn (OTL) is an important concept to describe and analyze learning and development in educational contexts (McDonnell, 1995). Deriving from studies conducted by the International Association for the Evaluation of Educational Achievement (IEA) such as TEDS-M, the concept of OTL is central when investigating the impact of teacher preparation on teacher learning: It serves "as an indicator of curricular variation among countries (...) and as a representation of the diversity of content" (Tatto et al., 2008, p. 44).

Building on this, our study makes use of the OTL concept, but we specifically focus on in-school OTL. During in-school OTL student teachers are able to apply their hitherto developed teaching skills (Wilson et al., 2001). They can practice a teaching concept, deepen their understanding and apply concepts by practical activities in the classroom (Clift \& Brady, 2005), and they can make use of critical thinking skills in order to become a "reflective practitioner" (Schön, 1987). The quality of such learning processes increase when support and feedback on his or her learning activities is available to the future teacher, so school-based mentoring of beginning teachers, the guidance and support of future teachers' supervisors is essential (Caires, Almeida \& Vieira, 2012; Hobson et al., 2009).

Thus we assume two major components of in-school OTL are decisive for a future teachers' role-taking: Activities related to their learning process such as lesson planning, teaching, linking theory to practice, and reflecting on practice on the one side and the social interaction with mentor teachers as the representatives of the profession on the other side who help future teachers "to adapt to the norms, standards and expectations associated with teaching in general" (Hobson et al., 2009, p. 209) and thus may introduce the future teachers into a "community of practice" (Lave \& Wenger, 1998).

However, how future teachers make use of in-school OTL not only depends on the requirements or the quality of a specific teacher education program, but also on their individual dispositions. For example, those future teachers who are highly motivated to work with children or adolescents will presumably also show stronger commitment when learning to practice with students at school than their fellows who might have chosen teaching for extrinsic reasons mainly (e.g., job security). As this may result in differential learning developments of future teachers during initial teacher education, in the following analysis we will make use of mediation models in which not only the impact of 
OTL on the change of teaching motivations is analyzed, but which enables us to simultaneously examine the influence entry motivations have on future teachers' use of OTL, i.e., their commitment towards learning to practice.

\subsection{Comparing Teacher Education in Austria, Germany, and Switzerland}

International comparative teacher education studies allow researchers to identify strengths and weaknesses of a teacher education system regarding its various factors such as structure, organization, content, or outcome (Blömeke \& Paine, 2008; Tatto et al., 2008). Our selection of the three German-speaking countries - Austria, Germany, and Switzerland - has the great advantage that validity is supported by similar linguistic and cultural background. However, since teacher education differs across Austria, Germany, and Switzerland in the way in-school OTL during initial teacher education are designed and provided, a comparison of how preservice teachers' teaching motivations change in association with the three countries' in-school OTL is of great interest. Since the theory-practice relationship in teacher education is a fundamental discussion in other countries as well (Clift \& Brady, 2005; Wilson et al., 2001), the comparative investigation of future teachers' school experience and teaching motivations also contributes to the global discourse of teaching and teacher education (Townsend \& Bates, 2007; Wang et al., 2011).

Future teachers in the German-speaking countries are provided with in-school OTL as early as during the first two years of initial teacher education. However, whereas in Germany school experience is limited to two or three practical elements with a duration of a few weeks only during that time (due to the split into a first phase at university with heavy focus on theory and a subsequent second practical phase (also called induction) in which future teachers have to teach regularly at school), the majority of preservice teachers in Austria and Switzerland have in-school OTL right from the beginning when they enter initial teacher education and to a far larger extent. Especially the teacher training colleges that do not differentiate into two phases due to a comparatively short initial teacher training (three years) offer teacher education programs in which theoretical learning is strongly linked to teaching practice in schools. Empirical evidence for these differences was shown in a recent analysis of curricular requirements of programs provided by 44 teacher education institutions in Germany, Austria, and Switzerland (Arnold, 2014). Two findings are of particular interest for our study: First, by average, the number of practical units is higher in Austria and Switzerland than in Germany. Second, in Switzerland, curricular requirements related to teaching responsibilities are higher than in Austria or Germany.

We assume that such differences in in-school OTL influence how student teachers explore and qualify their career decisions. More specifically, we assume that the three countries differ with regards to how much field experience is regulated during the bachelor's program, ranging from a 'sink or swim' process in programs with heavy focus on theory (Germany) to a more directed approach where programs are much more orientated towards practical training (Austria) and even higher teaching responsibilities (Switzerland). Findings from such a comparison will enrich current reform debates on the improved integration of practice in initial teacher education currently led in Germany, Austria, and Switzerland (Bosse et al., 2012). Moreover the results will provide empirical evidence to the internationally highlighted importance of field experiences in teacher preparation (Darling-Hammond et al., 2005).

\subsection{Research Question and Hypotheses}

We assume that preservice teachers' motivation for choosing teaching as a career change during initial teacher education due to experiences they gain through in-school opportunities to learn. The major implication of this expected overall result will be to learn that teaching motivations are dynamic and part of future teachers' professional learning process rather than fixed to the time point only when student teachers enter their program. To investigate this on a more detailed level, we raise three questions:

1) Do teaching motivations change?

2) Do in-school opportunities influence teaching motivations?

3) Do teaching motivations that the future teachers have when entering initial teacher education influence the way they make use of in-school OTL?

In order to investigate teaching motivations, we refer to the well-known framework "Factors Influencing Teaching as a Career Choice" (FIT-Choice) developed by Watt and Richardson (2008; Richardson \& Watt, 2014). It is a model which is founded on expectancy-value theory and the international state of research on future teachers' motivations for choosing teaching as a career. The model consists of several factors that specifically influence future teachers' decision to become a teacher (Figure 1). 


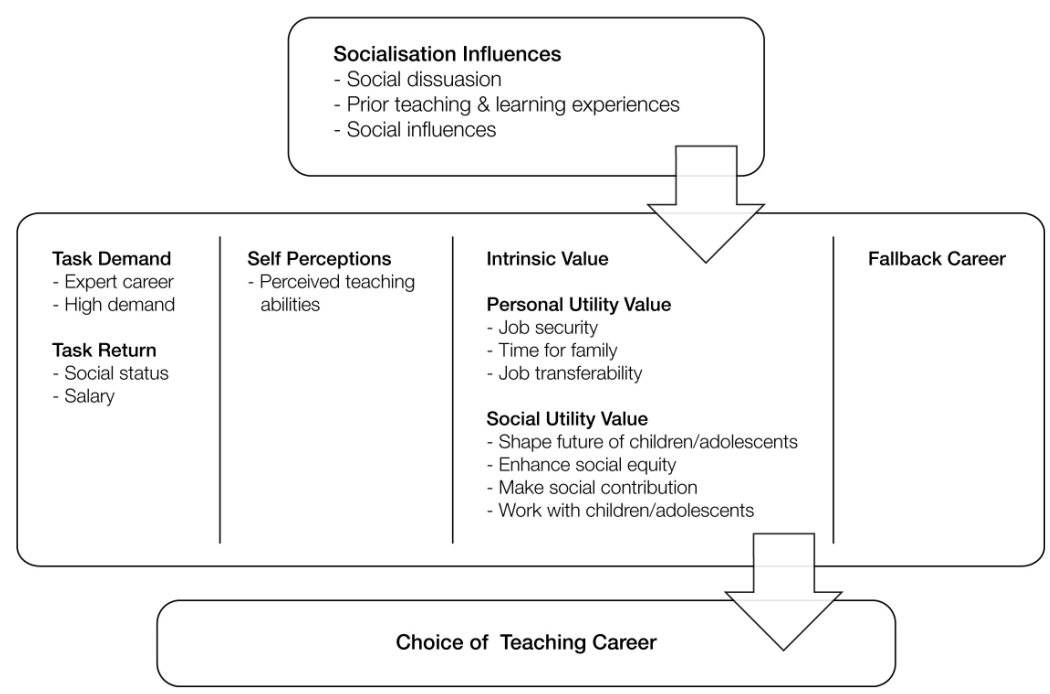

Figure 1. The FIT-Choice theoretical model (Richardson \& Watt, 2010, p. 151)

We focus on eight motivational factors that we assign to intrinsic, extrinsic, and altruistic-type motivations as the most frequently investigated teaching motivations (see Table A2 in the Appendix): Intrinsic and extrinsic motivation comprise two factors each (intrinsic motivation: "intrinsic value", "perceived teaching ability"; extrinsic motivation: "job security", "time for family"), whereas altruistic-type motivation consist of four factors ("shape future", "enhance social equity", "make social contribution", "work with children/adolescents"). In our study, we use the following hypotheses related to the three research questions:

(1) Reflecting about one's own teaching motivation is a curricular requirement for student teachers. For this, role-taking is necessary. We hypothesize that those motivations should change which are close to initial teacher education and the typical vocational challenges such as "perceived teaching ability" (as part of intrinsic motivations) or "work with children/adolescents" (as part of altruistic-type motivations) (we denote this as hypothesis 1a, in the following abbreviated as H1a). In contrast, distal motivations such as "time for family" (as part of extrinsic motivations) should hardly change (H1b).

(2) Learning to practice during in-school OTL activates the student teacher, since it is closely related to the act of teaching, i.e., close to what they are motivated for genuinely. On a detailed level however, when considering the various teaching motivations, we assume that intrinsic teaching motivations, but also altruistic-type motivations should be associated with the experiences future teachers gain during their in-school OTL.

Intrinsic teaching motivations are considered to be "the main focus of several models in the motivation literature" (Richardson \& Watt, 2014, p. 5). They are "emphasized as major influences within the expectancy-value framework" (p. 8). Consistently, the two intrinsic factors "perceived ability" and "intrinsic value" were among the highest-rated motivations for choosing teaching as a career in previous studies (Rothland, 2014; Richardson \& Watt, 2014; Watt et al., 2012). To foster future teachers' "perceived teaching ability" is one of the main goals of in-school OTL (Wilson et al., 2001) with the possible consequence of an increase of their "intrinsic value" for teaching. Thus we assume indicators for in-school OTL such as future teachers' learning activities and mentoring lead to an increase of "perceived teaching ability" and "intrinsic value" (H2a).

Altruistic-type motivations, denoted as "social utility values" - a higher-order value construct in the integrative FIT-Choice model (see Watt \& Richardson, 2008) comprising the four teaching motivations "shape future of children/adolescents", "enhance social equity", "make social contribution", and "work with children/adolescents" (see Figure 1 and Table A2) - obviously are highly endorsed motivations of young people choosing teaching as a career (Rothland, 2014; Watt et al., 2012). However, there is the question to what extent initial teacher education is capable to foster such motivations during the first three years. Compared with the coursework at university, in-school OTL provide the unique option for future teachers to come in personal contact with children or adolescents at school. This kind of social interaction should influence altruistic-type motivations, at least as long as it helps future teachers to build on and confirm their choice for teaching as a career. We assume that future teachers who make extensively 
use of such OTL will report an increase of their altruistic-type motivations, whereas those who are less committed with their practical learning activities will draw a distance or experience a loss of altruistic-type teaching motivations, also possibly because they realize their former agreement was partly illusionary $(\mathrm{H} 2 \mathrm{~b})$.

Extrinsic motivations such as "job security" or "time for family" should, by contrast, not be shaped by in-school OTL $(\mathrm{H} 2 \mathrm{c})$. These teaching motivations are too distal from the general objectives of initial teacher education and the specific curricular requirements future teachers have to fulfill during in-school OTL.

Due to differences between Austria, Germany, and Switzerland in the way how in-school OTL is provided and organized, we assume the influence of OTL on teaching motivations increases with the priority a teacher education program gives to in-school OTL. Since, right from the start, teacher education in Austria and Switzerland is much more focused on learning to practice than teacher education in Germany we assume stronger effects for Austria and Switzerland than for Germany. Additionally, due to the requirement of increased teaching responsibilities for student teachers in Switzerland as analyzed on the program level (Arnold, 2014), we also expect stronger effects for Switzerland when compared with Austria (H2d).

(3) While future teachers' teaching motivations are likely to be mainly related to the point of time when entering teacher education, it is highly important to examine the extent to which such motivations have an influence on future teachers' professional development during initial teacher education. Future teachers with relatively strong intrinsic teaching motivations and being interested to work with children might make use of teacher education opportunities to learn to a larger extent than their fellow students who show high extrinsic values. So we assume positive effects of beginning student teachers' intrinsic teaching motivations and altruistic-type motivations, whereas we assume negative effects of extrinsic motivations on the indicators we use to capture future teachers' in-school OTL (H3).

\section{Method}

\subsection{Participants}

The data set derives from the comparative study Change of Teaching Motivations and Acquisition of Pedagogical Knowledge during Initial Teacher Education (EMW - Entwicklung von berufsspezifischer Motivation und pädagogischem Wissen in der Lehrerausbildung). With the support of a network of about 40 research partners from Germany, Austria, and Switzerland preservice teacher cohorts who started in winter term 2011 were sampled at two time points (T1: Autumn 2011, T2: Autumn 2013). 6,601 student teachers from 31 universities/teacher training colleges were sampled at the first time point, representing a population of nearly 50,000 preservice teachers at the beginning of their teacher education (König et al., 2013). In the institutions of the research partners, student teachers were surveyed during compulsory lectures thus preventing self-selection during participation. However, the panel sample used in the analysis presented here refers only to 1,779 student teachers who could be followed up to participate at T2, when they were in their last year of their 3-years bachelor's program. They come from 19 universities/ teacher training colleges (see, for more details, Table A1 in the Appendix), where research partners were able to reliably survey student teachers. Within these 19 institutions, a total of 39 programs were represented by the student teachers surveyed allowing them to pursue a primary school teaching career, a secondary school teaching career, or other types of teaching careers (e.g., special needs education), thus covering a broad heterogeneity of program types in each country with the exception in Switzerland where primary and secondary level from one institution was covered only. By average, 46 student teachers represent one program $(\mathrm{SD}=44)$.

\subsection{Instruments}

\subsubsection{Teaching Motivations}

The German translation of the FIT-Choice scale inventory documented by Watt et al. (2012) was used. We focus on eight motivational factors that we assign to intrinsic, extrinsic, and altruistic-type motivations (see Table A2) as the most frequently investigated teaching motivations. These motivations were measured by a total of 24 items which future teachers surveyed had to respond to after the introductory sentence „I chose to become a teacher because ..." (T1) and "I want to become a teacher because..." (T2). Item response options ranged from 1 ("not at all important") to 7 ("extremely important"). Confirmatory factor analysis was carried out for each time point with acceptable model fit $\left(\mathrm{T} 1: \chi^{2} / \mathrm{df}=3.11, \mathrm{p}<.001, \mathrm{CFI}=.911, \mathrm{RMSEA}=.060, \mathrm{SRMR}=.059 ; \mathrm{T} 2: \chi^{2} / \mathrm{df}=3.44, \mathrm{p}<.001\right.$, $\mathrm{CFI}=.904, \mathrm{RMSEA}=.065$, SRMR $=.061$ ) giving evidence for the FIT-Choice inventory structure in our sample. Due to high inter-correlation of factors, the items measuring "shape future", "enhance social quality", and "make social contribution" were taken together to measure one latent variable only (hence in the following denoted as "shape future/ Enhance social equity/ Make social contribution"). Table A2 in the Appendix contains results on scale reliability and item examples. 


\subsubsection{In-School Opportunities to Learn}

The measurement instrument we apply had been developed for cross-national comparisons in the EMW-study. It comprises activities conducted and school-based mentoring. Some of its items were derived from TEDS-M (Tatto, 2013) and modified, but the majority was specifically developed anew for the present study. This process included two pilot studies and several item reviews in which teacher education experts from all three countries participated, providing evidence on construct, curricular, and criterion validity (König et al., 2014; König \& Klemenz, 2015).

Preservice teachers' activities were captured with four scales, each of them comprise several items: lesson planning (12 items, $\alpha=.83$, e.g., "I have formulated learning goals aligned to the curriculum."), teaching ( 31 items, $\alpha=.90$, e.g., "I have checked attendance.", "I have handed on differentiated activities to the students.", "I have told students how to self-evaluate their learning."), linking theories to situations (11 items, $\alpha=.83$, e.g., "I have observed teaching methods that I have learned at my university/teacher training college course."), and reflecting on practice (11 items, $\alpha$ $=.78$, e.g., "I have analyzed my teaching", "I have drawn conclusions for future teaching."). Items were introduced using the initial question "During your in-school OTL have you conducted the following activities?" and student teachers had to answer with "Yes" (coded as 1) or "No" (coded as 0 ) which results in scale scores ranging from 0 to 1.

School-based mentoring was captured by four items that had to be rated on four-point Likert scales ranging from "strongly disagree" (coded as 1) to "strongly agree" (coded as 4). Items were prompted by the initial question "Have you gained the following experiences during your in-school OTL?" and examples of items are "A teacher has posed questions to me about my teaching that inspired me to reflect on practice." and "A teacher has shown me possible ways of how to improve my teaching."

\subsubsection{Background Variables}

To account for individual characteristics of future teachers in the following analysis, we control for demographics (age, gender), Grade Point Average (GPA) as an indicator for cognitive ability, ranking from "1" (very good) to "4" (sufficient), and the social status, which is operationalized using the highest occupational status that exists among a future teacher's parents (HISEI, following the concept of International Socio-Economic Index of Occupational Status by Ganzeboom, de Graaf, \& Treiman, 1992).

\subsection{Data Analysis}

First, we use a paired-sample t-test to test if the means in the teaching motivations are significantly different between T1 and T2. Practical relevance will be indicated with Cohen's d (Cohen, 1988) allowing us to answer our first research question. Second, stability will be analyzed on the level of latent constructs and by applying path modelling (see Figure 2, upper part). Third, when we examine hypothesized relationships between in-school OTL and teaching motivations we extend the stability model by OTL-indicators and thus alter it into a mediation model (see Figure 2, lower part) which allows us to simultaneously generate findings for examining our second and third research questions. Whereas with our second research question we ask for path coefficients denoted as c in Figure 2, with our third research question we ask for path coefficients denoted as $b$. In order to specify mediation models for each teaching motivation and for each of the OTL-indicators (i.e., activities on the one hand, mentoring on the other hand), we use OTL measures on a latent variable level. For this, the four activities scales are used as manifest variables to model the latent variable "activities", whereas the four items measuring mentoring are used as manifest variables to model the latent variable "mentoring".

Using the software Mplus (Muthén \& Muthén, 1998-2010), countries are specified with the multigroup-analysis option, whereas stratification of sample (i.e., institutions such as university/teacher training college and teacher education programs) is specified via the complex-type analysis option. Missing data is handled by using the full information maximum likelihood option, i.e., a model-based imputation procedure implemented in Mplus (Muthén \& Muthén, 1998-2010). 

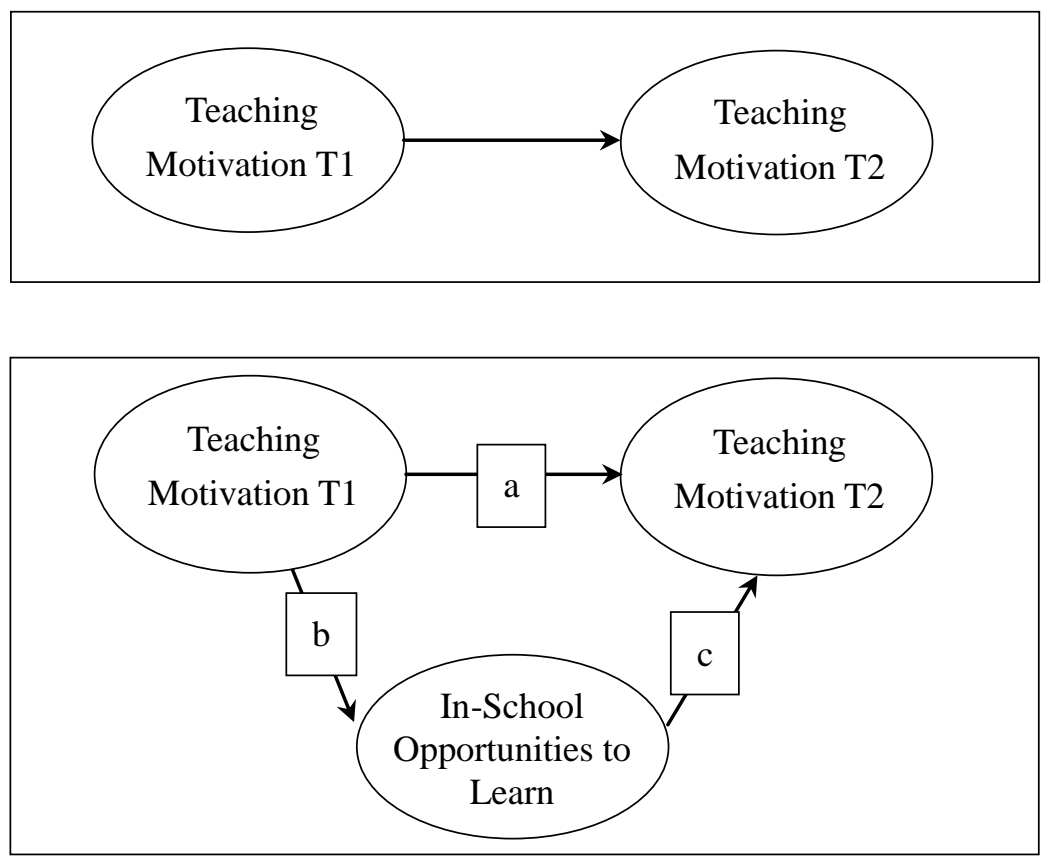

Figure 2. Model of Stability (upper part) and Mediation Model (lower part)

\section{Findings}

\subsection{Change of Teaching Motivations}

There is an increase of preservice teachers" "intrinsic value" in mean differences with practical relevance in Austria and Switzerland (indicated with Cohen's $|\mathrm{d}| \geq .20$; cf. Cohen, 1988). Moreover, in Switzerland future teachers report an increase in "perceived teaching abilities", but a decrease in the altruistic-type motivations (factors "shape future", "enhance social equity", and "work with children or adolescents"), which is also practically relevant. As previously assumed, motivations distal to initial teacher education (factors "job security" and "time for family") do not change to the extent of practical relevance in any country. Although mean differences in Germany are statistically significant, they are not practically relevant $(|\mathrm{d}|<.20)$. Table A3 in the Appendix contains further statistical results for teaching motivations at the two time points.

\subsection{Stability of Teaching Motivations}

To examine stability of teaching motivations on a latent variable level, we specified stability models as illustrated in the upper part of Figure 2 using structural equation modelling. Correspondingly, Table A4 in the Appendix contains the details of the latent path coefficients for teaching motivations at T2 regressed on T1, which were controlled for student teachers' age, gender, GPA, and HISEI. The majority of the teaching motivation stability is in the midrange (between .49 and .65). By contrast, relatively high stability can be found in Germany for the intrinsic career value (.82) and in Switzerland for the extrinsic motivation to have time for family (.76). Relatively low stability can be found in Switzerland for perceived teaching ability (.44) and intrinsic career value (.39).

\subsection{Differences in In-school OTL by Country}

To provide an analysis of differences in in-school OTL by country, mean differences of the preservice teachers were examined (see Table A5 in the Appendix for details). On each scale, preservice teachers in Switzerland agreed more strongly than those in Austria, whereas preservice teachers in Germany showed lowest agreement. These country mean differences are practically relevant as shown by a variance component analysis (Table A6). Between 14 and 34 percent variation can be explained by country, whereas program characteristics within university or teacher training colleges are very small (between 1 and 3 percent). This finding gives reason to look at country-specific relations between OTL and motivations. 


\subsection{Teaching Motivations and In-school OTL}

The stability models were extended by OTL indicators and thus altered into mediation models as illustrated in the lower part of Figure 2 in order to examine our second and third research questions. As illustrated in Figure 2, path "a" is the specific teaching motivation at T2 regressed on T1, path coefficient " $\mathrm{c}$ " is the effect the activities or mentoring have on the change of teaching motivation, whereas path "b" shows how teaching motivations at T1 may influence preservice teachers' report on how they have carried out activities or the extent to which they have been mentored. Findings for the first two factors "perceived teaching ability" and "intrinsic value" are presented in Figure 3 accordingly. All findings are documented in Table A7 and A8 in the Appendix.

Regarding our second research question, findings show a higher amount of activities of future teachers obviously strengthen their "perceived teaching ability" (.18/.10/.33) and foster their "intrinsic value" (.11/.13/.28), especially in Switzerland (Figure 3 and Table A7). However, their effects on enhancing altruistic-types of motivation for teaching are scarce (Table A7). A statistically significant effect can be found in the German sample, but the coefficient is low $(\beta<.1)$. Moreover, mentoring helps future teachers to enhance their "perceived teaching ability" $(.21 / .14 / .14$, with an exact $\mathrm{p}=.095$ in the Swiss sample) and their "intrinsic value" (.17/.21/.28) (Figure 3 and Table A8). Similarly, there are slight effects on altruistic-type teaching motivations for the Austrian sample (.14/.16) (Table A8). Extrinsic teaching motivations ("job security", "time for family") are not statistically significantly influenced by OTL measures (with the tiny exception of "time for family" in Austria).

With regards to our third research question, in Germany and Austria we find teaching motivations influence the amount of activities. Future teachers report having carried out a larger amount of activities during in-school OTL if they had entered initial teacher education with higher perceived teaching ability (.17/.19), higher intrinsic career value (.27), or higher altruistic motivations such as working with children/adolescents (.14/.19) or the comprising factors (.15/.19). A higher level of teaching motivation such as intrinsic career value (.17/.19) - in Austria also perceived teaching abilities (.14) and work with children/adolescents (.17) - also seems to help them to receive a higher level of support through mentor teachers. No such effects can be found for the Swiss sample.
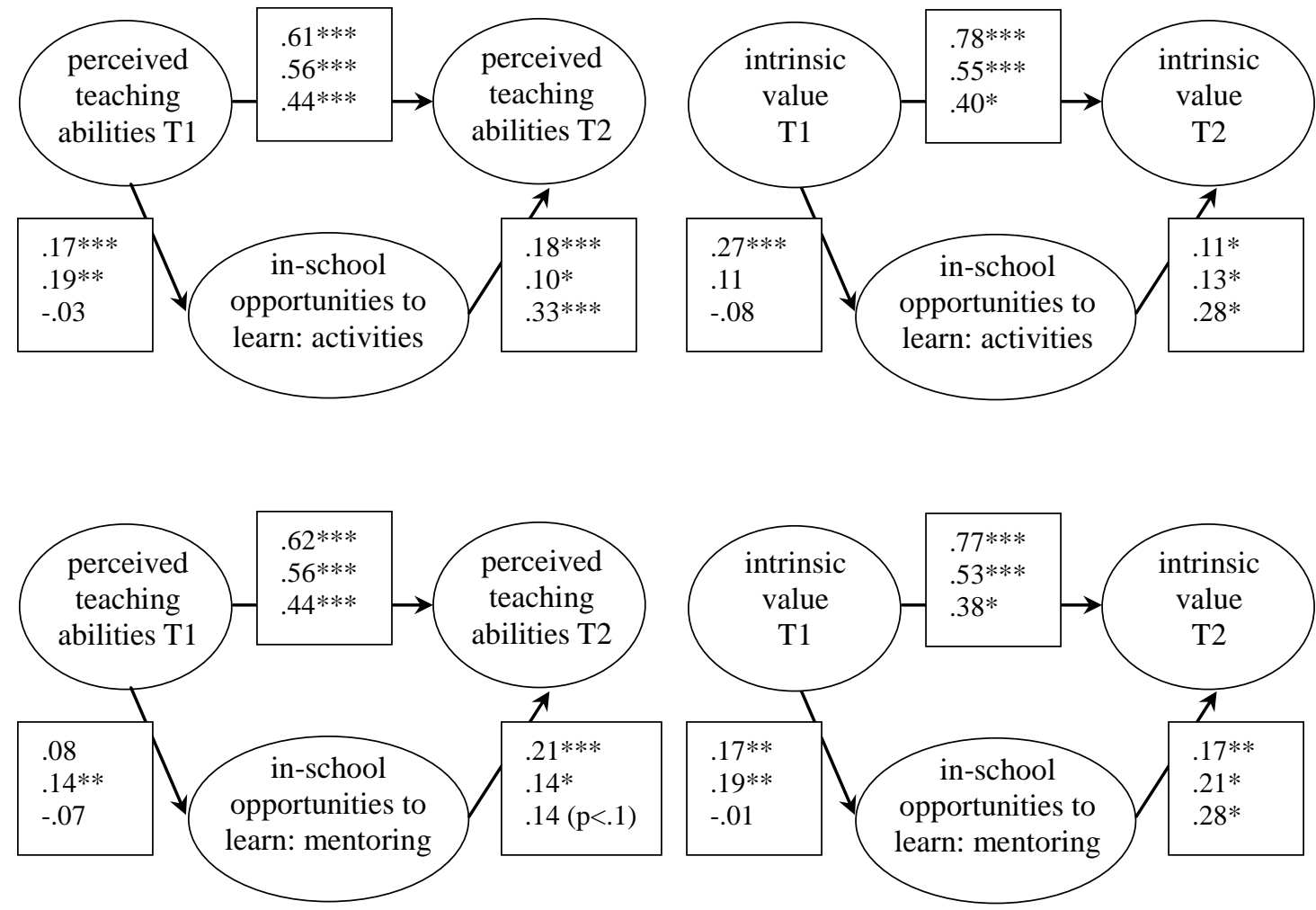

Note: $* \mathrm{p}<.05 * * \mathrm{p}<.01 * * * \mathrm{p}<.001$

Figure 3. Path coefficients by country (Germany, Austria, Switzerland) for mediation models including teaching motivations and in-school OTL (controlled for age, gender, GPA, and HISEI) 


\subsection{Summary of Results}

In our study, we asked whether student teachers' motivations for choosing teaching as a career change during initial teacher education and whether motivations are shaped by in-school OTL they had been exposed to.

Regarding our first research question, as we had hypothesized, teaching motivations change during the first two years of initial teacher education: Motivations proximal to initial teacher education such as "perceived teaching ability" or "intrinsic value" increased (H1a), whereas the distal ones such as "time for family" did not change (H1b). However, H1b could only be confirmed for Switzerland and partly Austria, where we have not only statistically significant mean differences, but also mean differences with practical relevance. Moreover, in contrast to our hypothesis (H1a) we found that altruistic-type motivations decrease, though with practical relevance only in the sample of Swiss future teachers.

Findings related to our second research question show that intrinsic motivations ("perceived teaching ability", "intrinsic value") are effected by OTL measures capturing activities and support by mentors thus confirming our hypothesis (H2a). Student teachers who report having conducted a higher amount of activities in the practical setting and having received a higher amount of support by a mentor positively change their intrinsic motivation for teaching as a career. This finding could be replicated in all three German-speaking countries, whereby in the Swiss sample with regression coefficients of $.33 / .28$, activities seem to be particularly influencing the increase of intrinsic motivation factors. This, but also the practically relevant changes in teaching motivations in the Swiss sample, partly matches our hypothesis (H2d) with which we had assumed stronger effects for Switzerland.

Moreover, we see that extrinsic motivations that are distal to initial teacher education ("job security", "time for family") are virtually not effected by in-school OTL, which confirms our hypothesis (H2c). Altruistic-type motivations such as "work with children/adolescents" are also effected by OTL measures (H2b), but this is only the case in the samples for Germany and Austria and predominantly restricted to mentoring.

Regarding our third research question, we see our hypothesis according to which entrance motivations would influence the amount of activities conducted or the mentor support perceived partly confirmed for Austrian and German preservice teachers (H3). Especially high "intrinsic value" among student teachers influences their commitment to conduct activities in in-school OTL.

\section{Discussion}

Our findings provide evidence that teaching motivations can change during initial teacher education and that they can be influenced by in-school OTL. Although effects are weak, this strengthens our overall assumption that teaching motivations are not just fixed to the time point when entering initial teacher education. Our study shows that teacher preparation matters for the change of student teachers' career choice motivation.

The main finding related to the change of the two factors "intrinsic value" and "perceived ability" generally confirms that among the various motivations of future teachers, intrinsic motivation is of great significance (Richardson \& Watt, 2014). However, whereas changes in the German sample are not practically relevant and in the case of the Austrian sample changes have a certain tendency only, in the Swiss sample the changes are more relevant, but with a small effect. So it seems that under the circumstance a teacher education program gives high priority to in-school OTL and requires relatively high teaching responsibility such as in Switzerland, motivations are more likely to be shaped. An explanation for this could be that higher teaching responsibility and professional support by mentors as reported by the Swiss preservice teachers (cf. Table A5) allows future teachers to be more satisfied with basic needs for autonomy and competence, both of which are decisive for developing interest and motivation according to the self-determination theory (Ryan \& Deci, 2000). Thus the increase in intrinsic teaching motivations effected by in-school OTL can be regarded as part of future teachers' professional development. Presuming that it is one of the goals of initial teacher education to foster preservice teachers' motivational development, an increase in intrinsic motivation for teaching as a career can be interpreted as evidence for teacher education effectiveness (Blömeke, Suhl, \& Kaiser, 2011). This is even strengthened when taking into account that research on teacher motivation has identified teachers' intrinsic motivation positively contributes to a teacher's performance in class and other outcomes (Kunter \& Holzberger, 2014).

Regarding Germany, where theoretical and less practical training is focused during the 3 years bachelor's program, one might argue that fostering intrinsic teaching motivations is not explicitly intended. Many surveys have repeatedly underlined the German student teachers' wish for an increase of practical training in the first phase of initial teacher education, leading to a predominant discussion about the gap between theory and practice (Hascher, 2014). The findings presented here may raise the question whether such a call for the increase of practical training is actually a student teachers' demand for making initial teacher education a more motivating enterprise. It seems that teacher education at universities in Germany is currently confronted with the challenges of how to solve the problem of 
integrating practice in the theoretical phase (Rothland \& Boecker, 2015), which is also a challenge in other countries (Ball \& Forzani, 2009).

Unexpectedly, in-school OTL did not increase altruistic-type motivations. Just to the contrary, a systematically decrease in such motivations could be observed by Swiss preservice teachers, who had come in contact with children or adolescents to the largest amount compared with preservice teachers in Austria and Germany. So the question arises whether those teaching motivations of future teachers that have already been judged to be as unrealistic and illusionary in the literature (Watt \& Richardson, 2008) become more realistic and tend to be less subject to social desirability. Moreover, the retreat of altruistic-type motivations might even be aligned to curricular goals of initial teacher education. Student teachers are required to change roles - from a former student role now to a role as a teacher. This may comprise to focus on typical vocational tasks and responsibilities of a teacher, to develop abilities to realistically judge on such tasks and responsibilities, and to draw a distance from the perception of teaching as a calling that often implies heavily overloaded and unrealistic expectations (Alexander, 2008). Now being confronted with the specific and concrete reality at school, now that they know much more about the serious duties and challenges of a teacher's everyday work, student teachers begin to draw a distance from their former global view of the teaching profession related to its significance in making a societal contribution. Instead, the more specific view of the teaching profession comes to the foreground - though with the advantage of comprising an increase in the specific interest in teaching (i.e., "intrinsic value", "perceived teaching ability"). The analysis of how in-school OTL differs across the three selected countries provides evidence that such role-taking was most likely required and fostered in the Swiss context of teacher education. Empirically, this is further strengthened by low stability and the lack of entrance characteristics influence in the Swiss sample (Figure 3).

Although our study brought about interesting findings, certain limitations have to be discussed as well. First, our study investigated teaching motivations at two time points. Although at T2 the majority of preservice teachers in Austria were in their last year of training before they would become fully certified, preservice teachers in Germany were not. It would be necessary to continue research and examine, for example, how teaching motivations may further change in the course of initial teacher education in Germany, where future teachers also enter the second practical phase with a heavy focus on teaching practice once they have finished their bachelor and master degree. On the basis of the findings presented here, one might argue that when they are exposed to in-school OTL similar to those of the Swiss future teachers reported here (see Tables A5 and A6), also German future teachers will increase their intrinsic teaching motivations to the extent of practical relevance. Second, as an innovative approach, our study linked measures of in-school OTL to teaching motivations. With the components of the OTL measures, it is possible to describe OTL in initial teacher education in the German-speaking countries. However, a much more detailed analysis could also be conducted, since teaching practice is a complex issue. In our mediation analysis, we aggregated four measures to one latent variable. Therefore, further research on how in-school OTL could be profoundly analyzed and measured seems to be necessary.

\section{Conclusion}

Numerous studies and reports of empirical teacher education research have investigated the question what motivates people to take on a career as a teacher. Teaching motivations are seen to be the first step into a teacher's professional career (Sinclair, 2008), but they are followed by role-taking when prospective teachers view their decision to become a teacher anew now from the perspective of someone who is actually becoming a teacher. This process bears the implication that teaching motivations are dynamic and part of future teachers' professionalization rather than fixed to the time point only when student teachers enter their program (Walkington, 2005). Teacher education programs are considered to influence future teachers' knowledge, skills, motivations, and attitudes, as research on the effectiveness of teacher education has conceptually worked out (Blömeke et al., 2011; Tatto et al., 2012). Since a person's interest for a specific vocation develops in association with preferred activities and by gaining experience in the relevant vocational field (Holland, 1997), in-school OTL are decisive for preservice teachers' further profiling of their teaching motivations. In-school OTL during teacher education vary across countries, as can be seen by the results of our comparison of bachelor's degree programs in the German-speaking countries (Bosse et al., 2012; Schwille et al., 2013). Moreover, findings also showed that teaching motivations are effected when compared in a sample with two time points, and there is variation that depends on the learning opportunities the preservice teacher had been being exposed to during their bachelor's program. Thus our conclusion is that in general it is worth extending research on teaching motivation by longitudinal research designs accounting for the dynamic of how future teachers' motivations may change and how their motivations are shaped by initial teacher education (cf. Opfer, 2014). Regarding our study, another two-year follow-up was conducted in 2015 thus measuring teaching motivations for the third time, when most of the Austrian and Swiss participants worked already as in-service teachers at school. How teaching motivations are transformed during the change from training into teaching will be another research question of our 
study that will bring about further findings to the question of how teaching motivation may change and be influenced by experience gained in the specific vocational field.

\section{Declaration of Conflicting Interests}

The author(s) declared no potential conflicts of interests with respect to the authorship and/or publication of this article.

\section{Acknowledgments}

This publication was made possible by grant number W-13-2-003 and W-15-2-003 from the Rhine-Energy-Foundation Cologne (Rhein-Energie-Stiftung Köln). Its contents are solely the responsibility of the authors and do not necessarily represent the official views of the Rhine-Energy-Foundation Cologne (Rhein-Energie-Stiftung Köln).

\section{References}

Alexander, P.A. (2008). Charting the course for the teaching profession: The energizing and sustaining role of motivational forces. Learning and Instruction, 18, 483-491. http://dx.doi.org/10.1016/j.learninstruc.2008.06.006

Arnold, K.-H. (2014). Unterrichtsversuche als allgemeindidaktische Lerngelegenheit: Eine vergleichende Curriculumsanalyse. In K.-H. Arnold, A. Gröschner, \& T. Hascher (Eds.), Schulpraktika in der Lehrerbildung. Theoretische Grundlagen, Konzeptionen, Prozesse und Effekte (pp. 63-86). Münster: Waxmann.

Arnold, K.-H., Hascher, T., Messner, R., Niggli, A., Patry, J.-L., \& Rahm, S. (2011). Empowerment durch Schulpraktika. Bad Heilbrunn: Klinkhardt.

Ball, D.L., \& Forzani, F.M. (2009). The work of teaching and the challenge for teacher education. Journal of Teacher Education, 60(5), 497-511. http://dx.doi.org/10.1177/0022487109348479

Blömeke, S. \& Paine, L. (2008). Getting the fish out of the water: Considering benefits and problems of doing research on teacher education at an international level. Teaching and Teacher Education, 24, 2027-2037. http://dx.doi.org/10.1016/j.tate.2008.05.006

Blömeke, S., Suhl, U., \& Kaiser, G. (2011). Teacher education effectiveness: Quality and equity of future primary teachers' mathematics and mathematics pedagogical content knowledge. Journal of Teacher Education, 62(2), 154-171. http://dx.doi.org/10.1177/0022487110386798

Bosse, D., Criblez, L., \& Hascher, T. (Hrsg.) (2012). Reform der Lehrerbildung in Deutschland, Österreich und der Schweiz. Teil 1: Analysen, Perspektiven und Forschung. Immenhausen: Prolog.

Brookhart, S. M., \& Freeman, D. J. (1992). Characteristics of Entering Teacher Candidates. Review of Educational Research, 62, 37-60. http://dx.doi.org/10.3102/00346543062001037

Caires, S., Almeida, L., \& Vieira, D. (2012). Becoming a teacher: Student teachers' experiences and perceptions about teaching practice. European Journal of Teacher Education, 35(2), 163-178. http://dx.doi.org/10.1080/02619768.2011.643395

Clift, R. T., \& Brady, P. (2005). Research on methods courses and field experiences. In M. Cochran-Smith \& K. M. Zeichner (Eds.), Studying teacher education. the report of the AERA Panel on Research and Teacher Education (pp. 309-424). Mahwah, NJ: Erlbaum.

Cohen, J. (1988). Statistical power analysis for the behavioral sciences (2nd ed.). Hillsdale, NJ: Lawrence Erlbaum Associates. http://www.jstor.org/stable/20182143

Darling-Hammond, L., \& Sykes, G. (2003). Wanted, A national teacher supply policy for education: The right way to meet the" highly qualified teacher" challenge. education policy analysis archives, 11, 33 .

Darling-Hammond, L., Hammerness, K., with Grossman, P., Rust, F. \& Shulman, L. (2005). The design of teacher education programs. In L. Darling-Hammond, \& J. Bransford (Eds.) Preparing teachers for a changing world: What teachers should learn and be able to do (pp. 390-441). San Francisco, CA: Jossey-Bass. http://dx.doi.org/10.14507/epaa.v11n33.2003

Ryan, R. M., \& Deci, E. L. (2000). Self-determination theory and the facilitation of intrinsic motivation, social development, and well-being. American Psychologist, http://dx.doi.org/10.1037/0003-066X.55.1.68

Fokkens-Bruinsma, M., \& Canrinus, E. T. (2012). The factors influencing teaching (FIT)-choice scale in a Dutch teacher education program. Asia-Pacific Journal of Teacher Education, 40(3), 249-269. http://dx.doi.org /10.1080/1359866X.2012.700043 
Ganzeboom, H. B., De Graaf, P. M., \& Treiman, D. J. (1992). A standard international socio-economic index of occupational status. Social science research, 21(1), 1-56.

Hascher, T. (2014). Forschung zur Wirksamkeit der Lehrerbildung. In E. Terhart, H. Bennewitz \& M. Rothland (Hrsg.), Handbuch der Forschung zum Lehrerberuf (S. 542-571, 2. überarb. und erw. Auflage). Münster: Waxmann.

Hobson, A.J., Ashby, P., Malderez, A., \& Tomlinson, P.D. (2009). Mentoring beginning teachers: What we know and what we don't. Teaching and Teacher Education, 25, 207-216. http://dx.doi.org /10.1016/j.tate.2008.09.001

Holland, J. L. (1997). Making vocational choices. A theory of vocational personalities and work environments ${ }^{\text {rd }}$ Ed.). Odessa, FL: Psychological Assessment Ressources.

König, J., \& Klemenz, S. (2015). Der Erwerb von pädagogischem Wissen bei angehenden Lehrkräften in unterschiedlichen Ausbildungskontexten: Zur Wirksamkeit der Lehrerausbildung in Deutschland und Österreich. Zeitschrift für Erziehungswissenschaft, 18 (2), 247-277. http://dx.doi.org/10.1007/s11618-015-0623-9

König, J., Rothland, M., Darge, K., Lünnemann, M. \& Tachtsoglou, S. (2013). Erfassung und Struktur berufswahlrelevanter Faktoren für die Lehrerausbildung und den Lehrerberuf in Deutschland, Österreich und $\begin{array}{llllll}\text { der Schweiz. Zeitschrift für Erziehungswissenschaft, } 16 & \text { (3), 553-577. }\end{array}$ http://dx.doi.org/10.1007/s11618-013-0373-5

König, J., Tachtsoglou, S., Darge, K. \& Lünnemann, M. (2014). Zur Nutzung von Praxis: Modellierung und Validierung lernprozessbezogener Tätigkeiten von angehenden Lehrkräften im Rahmen ihrer schulpraktischen Ausbildung. Zeitschrift für Bildungsforschung, 4 (1), 3-22. http://dx.doi.org/10.1007/s35834-013-0084-2

Kunter, M., \& Holzberger, D. (2014). Loving Teaching: Research on Teachers' Intrinsic Orientations. P.W. Richardson, S.A. Karabenick, \& H.M.G. Watt (eds.), Teacher Motivation. Theory and Practice (pp. 83-99). New York: Routledge.

Kyriacou, C., Hultgren, Å., \& Stephens, P. (1999). Student teachers' motivation to become a secondary school teacher in England and Norway. Teacher Development, 3(3), 373-381. http://dx.doi.org /10.1080/13664539900200087

Lave, J. \& Wenger, E. (1998). Communities of Practice: Learning, Meaning, and Identity: Cambridge University Press.

Lin, E., Shi, Q, Ang, J., Zhang, S., \& Hui, L. (2012). Initial motivations for teaching: comparison between preservice teachers. Asia-Pacific Journal of Teacher Education, 40(3), 227-. http://dx.doi.org /10.1080/1359866X.2012.700047

Lortie, D. (1975). Schoolteacher: A sociological study. Chicago: The University of Chicago Press.

Mayr, J. \& Rothland, M. (2013). Soll ich Lehrer/in werden? Anregungen zur Reflexion der Berufswahl [Should I become a teacher? Impulse on reflecting vocational choice]. In K. Zierer (ed.), Leitfaden Schulpraktikum [Guidline school practicum] (pp. 144-148). Berlin: Cornelsen.

McDonnell, L.M. (1995). Opportunity to learn as a research concept and a policy instrument. Educational Evaluation and Policy Analysis, 17(3), 305-322. http://dx.doi.org /10.3102/01623737017003305

Moran, A., Kilpatrick, R., Abbott, L., Dallatt, J., \& McClune, B. (2001). Training to teach: Motivating factors and implications for recruitment. Evaluation and Research in Education, 15, 17-32. http://dx.doi.org /10.1080/09500790108666980

Muthén, B.O., \& Muthén, L.K. (1998-2010). Mplus (Version 4.2) [Computer software]. Los Angeles, CA.

Nauta, M.M. (2010). The Development, Evolution, and Status of Holland's Theory of Vovational Personalities: Reflections and Future Directions for Counseling Psychology. Journal of Counseling Psychology, 57, 11-22.

Opfer, V.D. (2014). Teacher Career Trajectories. In P.W. Richardson, S.A. Karabenick, H.M.G. Watt (eds.), Teacher Motivation. Theory and Practice (pp. 214-226). New York: Routledge.

Putnam, R.T., \& Borko, H. (2000). What do new views of knowledge and thinking have to say about research on teacher learning? Educational researcher, 4-15. http://www.jstor.org/stable/1176586

Richardson, P.W., \& Watt, H.M.G. (2010). Current and future directions in teacher motivation research. In T.C. Urdan \& S.A. Karabenick (Eds.), The decade ahead: Applications and contexts of motivation and achievement (Advances in motivation and achievement, Volume 16B, pp. 139-173). Bingley: Emerald

Richardson, P.W., Karabenick, S.A., Watt, H.M.G. (Eds.) (2014). Teacher Motivation. Theory and Practice. New York: Routledge. 
Richardson, P.W., \& Watt, H.M.G. (2014). Why People Choose Teaching as a Career. An Expectancy-Value Approach to Understanding Teacher Motivation. P.W. Richardson, S.A. Karabenick, \& H.M.G. Watt (eds.), Teacher Motivation. Theory and Practice (pp. 3-19). New York: Routledge.

Rothland, M. (2014). Warum entscheiden sich Studierende für den Lehrerberuf? Berufswahlmotive und berufsbezogene Überzeugungen von Lehramtsstudierenden [Why decide students to become a teacher? Teaching motivations and beliefs of student teachers]. In E. Terhart, H. Bennewitz \& M. Rothland (Hrsg.), Handbuch der Forschung zum Lehrerberuf [Handbook on research on teachers] (2nd Ed., pp. 319-348). Münster u.a.: Waxmann.

Rothland, M. \& Boecker, S.K. (2014). Wider das Imitationslernen in verlängerten Praxisphasen. Potenzial und Bedingungen des Forschenden Lernens im Praxissemester. Die Deutsche Schule, 106 (4), 389-400.

Rots, I., Aelterman, A., Devos, G., \& Vlerick, P. (2010). Teacher education and the choice to enter the teaching profession: A prospective study. Teaching and Teacher Education, 26(8), 1619-1629. . http://dx.doi.org /10.1016/j.tate.2010.06.013

Ryan, R.M., \& Deci, E.L. (2000). Self-determination theory and the facilitation of intrinsic motivation, social development, and well-being. American Psychologist, http://dx.doi.org/10.1037/0003-066X.55.1.68

Schön, D. A. (1987). Educating the reflective practitioner: Toward a new design for teaching and learning in the professions. San Francisco.

Schwille, J., Ingvarson, L., \& Holdgreve-Resendez, R. (2013). TEDS-M encyclopedia: A guide to teacher education context, structure and quality assurance in the seventeen TEDS-M countries. East Lansing, MI: Michigan State University.

Sinclair, C. (2008). Initial and changing student teacher motivation and commitment to teaching. Asia-Pacific Journal of Teacher Education, 36, 79-104. http://dx.doi.org/10.1080/13598660801971658

Tatto, M.T. (Ed.) (2013). Teacher Education and Development Study in Mathematics (TEDS-M): Policy, Practice, and Readiness to Teach Primary and Secondary Mathematics. Technical Report. Amsterdam: IEA.

Tatto, M.T., Ingvarson, L., Schwille, J., Peck, R., Senk, S.L., \& Rowley, G. (2008). Teacher Education and Development Study in Mathematics (TEDS-M): Policy, Practice, and Readiness to Teach Primary and Secondary Mathematics. Conceptual Framework. Amsterdam: IEA.

Tatto, M.T., Schwille, J., Senk, S., Ingvarson, L., Rowley, G., Peck, R., Bankov, K., Rodriguez, M., \& Reckase, M. (2012). Policy, practice, and readiness to teach primary and secondary mathematics in 17 countries. Findings from the IEA teacher education and development study in mathematics (TEDS-M).

Thomson, M.M., Turner, J.E., \& Nietfeld, J.L. (2012). A typological approach to investigate the teaching career decision: Motivations and beliefs about teaching of prospective teacher candidates. Teaching and Teacher Education, 28(3), 324-335. http://dx.doi.org/10.1016/j.tate.2011.10.007

Townsend, T., \& Bates, R. (Eds.) (2007). Handbook of Teacher Education. Globalization, Standards and Professionalism in Times of Change. Dordrecht: Springer.

Walkington, J. (2005). Becoming a teacher: Encouraging development of teacher identity through reflective practice. Asia-Pacific Journal of teacher education, 33(1), 53-64. http://dx.doi.org/10.1080/1359866052000341124

Wang, J., Lin, E., Spalding, E., Odell, S.J., \& Klecka, C.L. (2011). Understanding Teacher Education in an Era of Globalization. Journal of Teacher Education, 62(2), 115-120. http://dx.doi.org/10.1177/0022487110394334

Watt, H.M.G., \& Richardson, P.W. (2008). Motivations, perceptions, and aspirations concerning teaching as a career for different types of beginning teachers. Learning and Instruction, 18(5), 408-428. http://dx.doi.org/10.1016/j.learninstruc.2008.06.002

Watt, H.M.G., \& Richardson, P.W. (2012). An introduction to teaching motivations in different countries: comparisons using the FIT-Choice scale. Asia-Pacific Journal of Teacher Education, 40(3), 185-. http://dx.doi.org/10.1080/1359866X.2012.700049

Watt, H.M.G., Richardson, P.W., Klusmann, U., Kunter, M., Beyer, B., Trautwein, U., \& Baumert, J. (2012). Motivations for choosing teaching as a career: An international comparison using the FIT-Choice scale. Teaching and Teacher Education, 28, 791-805. http://dx.doi.org/10.1016/j.tate.2012.03.003

Wilson, S., Floden, R., \& Ferrini-Mundy, J. (2001). Teacher preparation research: Current knowledge, gaps, and recommendations. Center for the Study of Teaching and Policy, University of Washington. 